\title{
Játék és matematika másfél órában
}

\section{Dályay Zsuzsanna}

SZTE JGYPK TÓKI Matematika Szakcsoport

\begin{abstract}
A Szegedi Tudományegyetem Juhász Gyula Pedagógusképző Karának Tanítóés Óvóképző Intézetében néhány éve bevezetésre került a választható tantárgyak között egy Játékos matematika kurzus, mely igen népszerü a hallgatók körében. A kurzus célja megismertetni a hallgatókkal a játék szerepét a matematikai gondolkodás fejlesztésében, matematikai tehetséggondozásban, és nem mellékesen megtapasztaltatni velük az önfeledt játék, a játékhelyzetekben történő gondolkodás örömét. $A$ félév során a hallgatók különböző logikai, stratégiai és egyéb olyan gondolkodtató játékokkal ismerkedhetnek meg, melyek eredményesen használhatóak a matematikai gondolkodáshoz szükséges képességek kialakitásában, fejlesztésében. A kurzus teljesitésének több feltétele van: témába illeszkedő (társas)játékot találni, és azzal játékot vezetni, - a szakirodalomban önállóan keresve - valamilyen matematikai témájú eszköz vagy modell készítését ismertetni órán, valamint saját ötleten alapuló, saját készítésű játékot bemutatni, tesztelni. Jelen írásban a kurzus tapasztalatairól szeretnék beszámolni, kitérve a hallgatók által leginkább kedvelt játékokra és azok matematikai vonatkozásaira.
\end{abstract}

Kulcsszavak: matematikai játékok, logikai játékok, Panic Lab, SET, Qwirkle

A Játékos matematika kurzus teljesítéséhez alapvető elvárás a hallgatók aktív jelenléte, szerepvállalása. Miközben kezdetben, óráról órára egyre több (oktató által bemutatott) játék megismerésében, kipróbálásában és elemzésében vehetnek részt a hallgatók, fokozatosan egyre nagyobb szerepet kap az ő önálló munkájuk is. Első feladataik közé tartozik behozni, bemutatni és játékot vezetni egy olyan (társas)játékkal, amely illeszkedik a kurzus tárgyához, azaz játszása alapvetően logikus, elemző gondolkodást igényel. Néha már ennek a megítélése is nehézséget okoz számukra, de ahogy a félév során egyre több játékot ismernek meg, egyre fogékonyabbakká és kreatívabbakká válnak. Második feladatuk valamilyen matematikai tartalommal is bíró játékos tevékenység szervezése (pl. gyufaátrakásos feladatok, hajtogatások stb.), majd a félév második felében saját ötletet is tartalmazó játékot kell készíteniük. Ezeket a játékokat az órán bemutatják, majd teszteljük is őket, így az elhangzó ötleteket, megjegyzéseket, beépíthetik a játékba vagy a játék (eszközének) egy új változatába.

A következőkben néhány olyan játékot ismertetünk, melyek a hallgatók által leginkább kedveltek közé tartoznak, és amelyeknek közös jellemvonása, hogy maga az eszköz logikaikészlet-jellegü. A Dienes Zoltán nevéhez füződő logikai készlet Magyarországon legelterjedtebb változata müanyag lapokból áll, melyek színük szerint lehetnek kékek, zöldek, pirosak vagy sárgák, alakjuk szerint négyzetek, háromszögek vagy körök, méretük szerint kicsik vagy nagyok, felületük szerint pedig lyukasak vagy simák, és a lapok között minden lehetséges verzió szerepel. Így a készlet elemeinek száma: $4 \cdot 3 \cdot 2 \cdot 2=48$. A logikai készlettel számos olyan játékos tevékenység is szervezhető, mely kiváló alapot nyújthat a halmazokkal és logikával kapcsolatos tapasztalatszerzéshez. Ahhoz, hogy a játékok, tevékenységek kapcsán felmerülő gondolatok elválhassanak az eszköztől, nagyon fontos a reprezentációk váltogatása. Ezt a logikai készlet mintájára készíthetö különböző készletek használatával is elérhetjük, de választhatunk a különböző játékkiadók logikai készlet hátterü játékaiból is. A továbbiakban ezek közül mutatunk be néhányat. 
Panic Lab (Dominique Ehrhard ötlete alapján; Gigamic):

A játék egy történet köré épül, mely szerint a játékosoknak különböző laboratóriumokból megszökött, szellőzőrácsok mögött bujkáló és menekülésük során különböző átalakulásokon áteső amőbákat kell megtalálniuk. Az amőbák formájuk szerint egy- vagy kétszemúek lehetnek, mintájuk alapján csíkosak vagy pöttyösek, a színük pedig piros vagy kék. Így $2 \cdot 2 \cdot 2 \cdot 2=8$ különböző amöbánk van, és a játékban mindegyik két példányban jelenik meg. A játék tartalmaz további lapokat is: 3 labor-, 3 mutációsszobaés 3 szellőzőrácskártyát, valamint négy dobókockát. A laborkártyák (piros, kék, sárga) egyetlen szerepe a kiindulás helyének megjelölése. A mutációs szobák mindegyikében egy-egy átalakuláson esik át az amőba: megváltozik a formája (szemeinek száma), a mintája vagy a színe. A szellőzőrácskártyák egyformák, és a pálya bizonyos szakaszait iktatják ki a keresés során (lásd az 1. ábrát ${ }^{1}$ ).

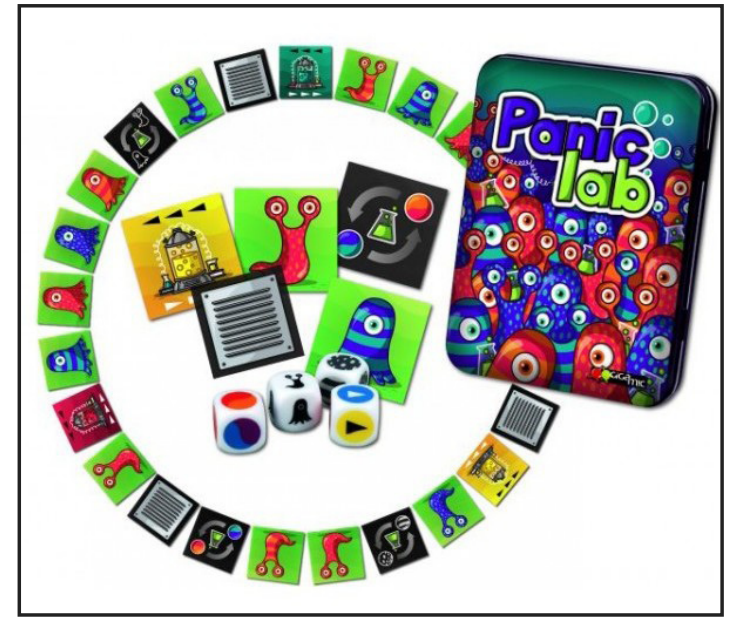

1. ábra: Panic Lab

A játék menete a következő: a 25 lapkát összekeverés után körberakjuk, ez alkotja a mindig változó ,játéktáblát”, majd a dobókockákkal kidobjuk a keresendő amőbát - melyet a három kockával kidobott forma, minta és szín határoz meg -, valamint a kiindulás helyét jelölő labor színét, a szökés irányával együtt - mindkettőt a negyedik kocka határozza meg. (Például, az illusztráción látható kidobás szerint a kétszemü piros pöttyös amőbát kell keresni, amelyik a kék laborból szökött meg a - laborkártyán is feltüntetett - fehér nyíl irányában.) A játék lényege az amőba mielőbbi megtalálása, az átalakulások helyes nyomon követésével, figyelembe véve a szellőzőrácsok szerepét is. A játékos tehát megkeresi a kiindulási pontként szolgáló labort, és innen elindul a pályán a kidobott irány szerint, egyenként megfigyelve a kártyákat: ha megtalálja a keresendő amőbát, készen van, ha azonban ezt megelőzően mutációs szobába botlik, akkor a továbbiakban már a mutálódott amőbát keresi, hiszen a történet szerint az amőba a menekülés során áthaladt ezen a szobán. (Előző példánkban, ha a kék laborból fehér nyíl irányában indulva, a kétszemü piros pöttyös amöba megtalálása elött egy színmutációs szobába botlunk, akkor ezentúl kétszemü kék pöttyös amőbát keresünk, mindaddig, amíg meg nem találjuk, vagy más mutáció miatt másmilyen formában nem keressük.) Ha az amőba megtalálása előtt szellőzőrácsba botlunk, akkor innen a következő szellőzőrácsig tartó szakaszt át kell ugornunk, és csak az ezt követő szakaszon folytathatjuk a keresést (majd a következő szellőzőrácstól megint kihagyunk egy szakaszt, és így tovább, felváltva keresünk, kihagyunk).

A játékot 2-10 fö játszhatja, a játékosok egyszerre vannak játékhelyzetben: noha a soron következő játékos dob a kockákkal, mégis mindenki egyszerre keresi a szökött amőbát, és aki a leggyorsabban megtalálja, rámutat. Pontot akkor kap, ha megindokolta és a többiek el is fogadták a válaszát. A játékot az nyeri, aki a legtöbb pontot gyüjti össze. (Természetesen a játék egyszemélyes verzióban is játszható.)

\footnotetext{
1 Kép forrása: http://jatek.origo.hu/gigamic-panic-lab-tarsasjatek.html
} 
A játékszabályok összetettek ugyan, de játék közben könnyen megérthetőek. $A$ fokozatosság érdekében, bevezető játék lehet az, ha kihagyjuk a szellőzőrácsokat a játékból. Noha a kiadó 8 éves kortól ajánlja, kisebbekkel is játszható, és könnyedén olyan gyerekekkel, akik ismerik a logikai készletet. A játékszabályok összetettsége elemzésre ad lehetőséget a hallgatók számára is. Általában a következő kérdések szoktak felmerülni:

- Megtörténhet-e, hogy a „szellőzőrácsszabály” pályaszakaszokat kiiktató tulajdonsága miatt nem találjuk meg a keresett amőbát? Nem! A páratlan számú szellőzőrács páratlan számú ívre osztja a pályát, így a pálya azon szakaszai, amelyek első körben kimaradnak, a második körben bejárhatóak, és fordítva.

- Mi a jelentősége a „szellőzőrácsszabálynak”, ha végül mégis bejárhatunk minden szakaszt (kivéve, ha már első körben előkerülne a szökött amőba)? Elsősorban a mutációs szobák sorrendjének meghatározásában, esetleg az amőba ideiglenes elrejtésében van szerepe.

- Előfordulhat-e az amőba útja során ugyanaz a mutációs szoba kétszer is? Előfordulhat, de ez csak az amőba harmadik körében történhet meg (az első teljes bejárás után), ami azt jelenti, hogy mindhárom mutációs szobán átjutott már, tehát ez a negyedik ilyen helyzete. Ekkor a játékszabály szerint az amőba végleg eltünik.

- Hány különböző sorrendben találkozhat amőba mutációs szobával, és mi az eredmény? $3+6+6=15$ de az átalakulások eredménye nem függ a sorrendtöl, csak attól, hogy hány mutációs szobán megy át az amőba, és melyek ezek. (Ez pedig 3+3+1=7 különböző lehetőség. Az átváltozások eredményeként végül is csak a másik 7 állapotba mutálódhat az amőba, és ez egybeesik azzal, amit az előbb megállapítottunk.)

SET (Marsha J. Falco, SET Enterprises):

A készlet olyan kártyákból áll, melyek rendelkeznek a következő tulajdonságok mindegyikének valamely lehetséges verziójával: szám (egy, kettő, három), szín (lila, zöld, piros), forma (ovális, rombusz, hullámos), kitöltés (üres, vonalkázott, teli), összesen $3 \cdot 3 \cdot 3 \cdot 3=81$ kártya. A játék során 12 kártyát helyezünk az asztalra, és ha bármelyik játékos felvesz közülük néhányat, újra 12-re egészítjük ki a táblát. $A$ játék célja olyan kártyahármasok gyüjtése (ezeket nevezzük SET-nek), melyek minden egyes tulajdonságot tekintve (tulajdonságon belül) vagy azonosak, vagy háromfélék. A játékosok egyszerre vannak játékhelyzetben: mindenki egyszerre keres SETet, és aki a leghamarabb talál egyet, felveheti, majd az a játékos nyer, aki a játék végéig a legtöbb kártyát gyűjtötte össze. Habár nagyon egyszerüen megfogalmazható a játékszabály, mégis gondot szokott okozni az értelmezése, a kártyahármasok gyüjtögetése pedig valóban komoly figyelmet igényel. Ennek megkönnyítése érdekében érdemes néhány egyszerübb játékkal kezdeni.

Logikai készlettel ismert tevékenység az egykülönbséges (két-, három- vagy négykülönbséges) sorozat alkotása: a logikai lapokat úgy rakjuk sorba, hogy bármely két egymást követő lap pontosan egy (illetve kettő, három vagy négy) tulajdonságban különbözzék. Ezeket bevezetésképpen a SET kártyáival is játszhatjuk, segítve ezzel a játékosokat a kártyák megismerésében és összehasonlításában. (Mivel a SET is logikai készlet, nagyon sok más olyan játékot is végigjátszhatunk vele, amelyet logikai készlettel lehet játszani.)

Másik egyszerübb kezdőjáték lehet, ha csak a kártyapakli egy részével játszunk a SET szabályai szerint, mondjuk a teli kártyákkal (27 db), és így csak három tulajdonságot (szám, szín, forma) kell figyelnünk. Ebben a játékban csak 9 kártyát helyezünk az asztalra. 
Próbáljuk most értelmezni a SET jelentését az alábbi kirakásban! Például az 1, 2, 3 kártyák SET-et alkotnak, mert számuk háromféle, színük háromféle, formájuk háromféle, kitöltésük pedig azonos. Az 1, 11, 12 kártyák azonban nem alkotnak SET-et: habár a számuk háromféle, színük háromféle, formájuk háromféle, a kitöltésük azonban kétféle. Találjuk most meg az összes SET-et az adott kirakásban! Ezek a következők: (1, 2, 3); (1, 7, 12); (2, 5, 10); (2, 7, 11); (3, 4, 8); (4, 5, 9).

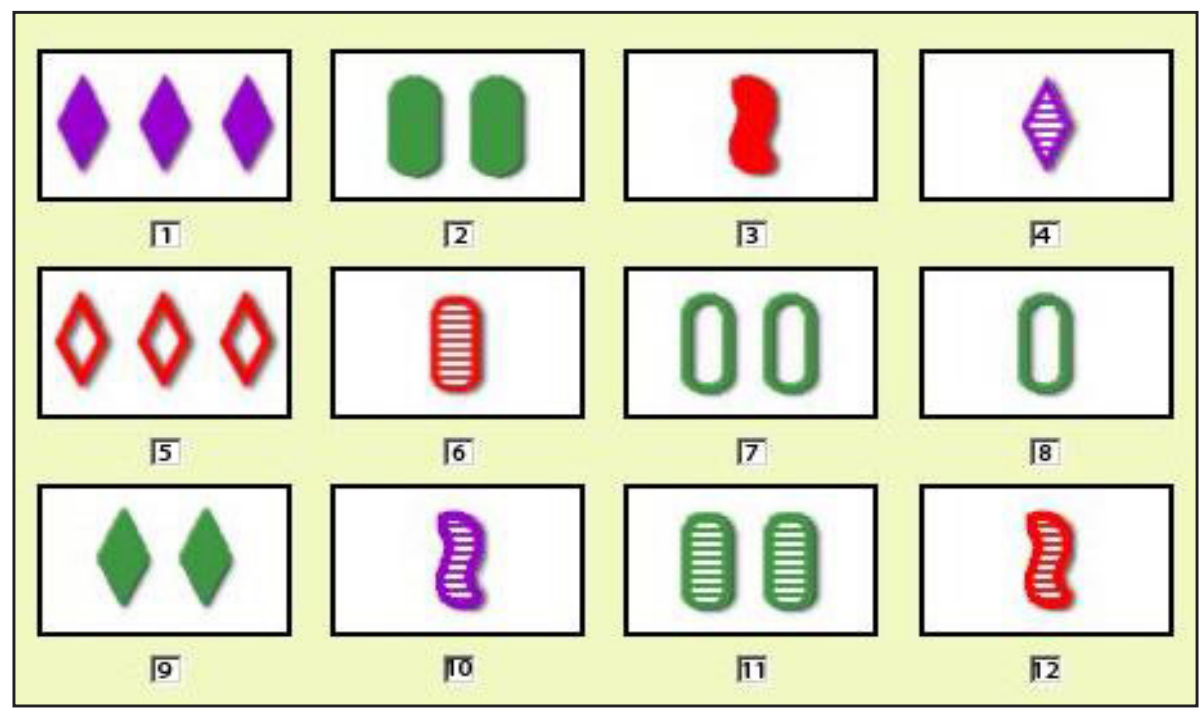

2. ábra: $\mathrm{SET}^{2}$

A hallgatókkal a következő kombinatorikai kérdések is elemezhetőek:

- A SET kártyáinak egykülönbséges sorozatba rendezése esetén, hány kártya kerülhetne egy adott kártya után? (8) Ugyanezt megkérdezhetjük két-, háromvagy négykülönbséges sorozat esetén is.

- Lehetséges-e, hogy a 12 letett kártya között ne legyen SET? Igen! Elszántabbak megpróbálkozhatnak ilyennek a kirakásával is.

- Hány különböző SET-ben lehet benne egy adott kártya? (40)

- Hány különbözö SET lehet a játékban? (1080)

Természetesen az előbbi kérdések némelyike nehéz lehet egy-egy hallgató számára, de volt már olyan csoport, amelyben felmerültek, és szívesen foglalkoztak velük.

A játék szerzője egyébként genetikai kutatásokat végzett Cambridge-ben, az epilepszia öröklődésének tényezőit vizsgálva kutyákon, és a könnyebb áttekinthetőség kedvéért ábrákkal jelölte az egyes információblokkokat, melyeket kártyákra jegyzett le. A kártyákat kiterítve az asztalon, azonosságokat és különbözőségeket keresett az ábrák között. Innen származik a játék ötlete, melyet később tökéletesítve, kiadott. A SET az egyik legtöbb díjat nyert bezsebelt játék.

Qwirkle (Susan McKinley Ross):

A készlet különböző négyzet alakú falapokból áll (nevezzük ezeket köveknek), melyek mintájuk szerint hatfélék, színük szerint pedig szintén hatfélék lehetnek (tehát öszszesen 36-féle kő van), és mindegyik kő három példányban (tehát összesen 108 kő) található a készletben (lásd a 3. ábrát ${ }^{3}$ ).

\footnotetext{
2 Kép forrása: http://www.nordinho.net/vbull/puzzles/10863-set-enterprises-daily-puzzles.html

3 Kép forrása: http://www.educatief-speelgoed.com/qwirkle-travel.html
} 


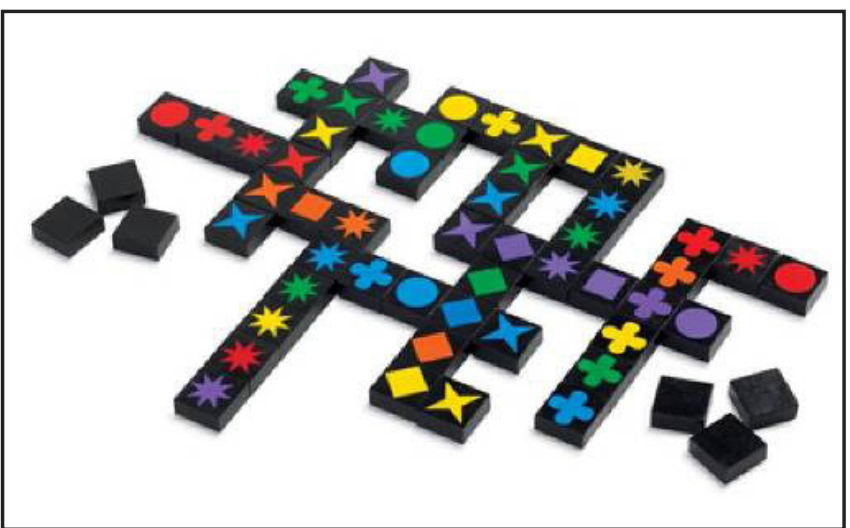

3. ábra: Qwirkle

A játékszabály hasonló a Scrabble játékszabályához: egyszerre egy követ vagy sorozatot játszhatunk ki úgy, hogy annak már letett kőhöz (esetleg kövekhez) kell kapcsolódnia valamint vízszintesen és függőlegesen is illeszkednie kell azokba a sorozatokba, amelyekhez hozzáér. Egy sorozat vagy azonos színü és különböző formájú köveket tartalmaz, vagy azonos formájú és különböző színúeket. (Tehát egy sorozat legalább 2, és legfeljebb 6 kőből állhat.) A pontozás is hasonló a Scrabble pontozásához: egy kő kijátszásakor annyi pontot kap a játékos, ahány kőből áll az a sorozat, amelyhez kapcsolódik (beleértve a már korábban lerakott köveket is). Ha a lerakott kő több sorozathoz is kapcsolódik, akkor minden ilyen sorozatnak megfelelően kap pontot. Ha a játékos sorozatot játszik ki, akkor a kijátszott sorozatért is kap pontot (a sorozat hosszúságának megfelelően), továbbá az általa lerakott kövekkel folytatott minden egyes sorozatért is. Ha egy játékos befejez egy sorozatot (Qwirkle-t hoz létre), akkor a sorozat hosszúságának megfelelő 6 pont mellé 6 bónuszpontot is kap. (Tehát egy Qwirkle 12 pontot ér.)

A kiadó 6 éves kortól ajánlja a játékot. Ekkora gyerekekkel érdemes bevezető játékként úgy játszani, hogy kiosztjuk az összes követ a játékosok között, és az nyer, akinek leghamarabb elfogynak a kövei. Így csak a helyes illeszkedésekre kell figyelni, és a pontok számolása, a minél több pontot eredményező kombinációk megtalálása fokozatosan építhető be a játékba.

A hallgatók nagyon hamar átlátják a szabályokat, és legtöbben gyorsan rájönnek a stratégiai lehetőségekre is. Néhány ezek közül:

- Gyakran több pont szerezhető egyetlen kő jól megválasztott elhelyezésével, mint egy hosszabb sorozat lerakásával.

- Öt kőből álló sorozat létrehozása kockázatos, hiszen felkínálja a többi játékos számára a Qwirkle könnyebb létrehozásának lehetőségét.

- Tudva, hogy minden kőböl összesen három van a játékban, figyelhetjük, hogy bizonyos pozícióba várható-e még megfelelő elem, vagy egy nálunk lévő kő jó lerakásának lehetőségét elronthatja-e másik játékos. (Az utóbbi gondolat inkább a játék vége felé értelmezhető.)

Érdemes megjegyezni, hogy a Spiel des Jahres zsürije 2011-ben a Qwirkle-t választotta meg az év játékának.

\section{Irodalom}

Bagota Mónika, Játékok a tanítóképzésben, (2014.04.08) http://www.nyme.hu/fileadmin/dokumentumok/atfk/apaczainapok/2010/Apaczai_napok_2009_tanulmanykotet_110216.pdf

Deme-Farkas Rita: Variációk a Set témájára, (2014.04.08) http://www.komal.hu/ cikkek/2008-02/SET.h.shtml

http://en.gigamic.com/game/panic-lab(2014.04.08)

http://www.setgame.com/set (2014.04.08)

http://www.mindware.com/p/Qwirkle/32016 (2014.04.08) 